\title{
Feasibility of groundwater desalination in the northeast of Brazil
}

Seasonal droughts occur in Northeast of Brazil by centuries, due to water shortage caused by the 2012-2018 severe drought, state governments have declared a state of emergency for most of the municipalities. As most of the municipalities depend on surface waters for the urban water supply system and the majority of water reservoirs in the Northeast being in a critical situation, the desalination of groundwater would be a feasible solution. This paper aims to identify municipalities in the state of emergency in the states of Ceará (CE), Rio Grande do Norte (RN), Paraíba (PB) and Pernambuco (PE) feasible for an implementation of a distillation desalination plant powered by a renewable energy source. In this context, the method used to discover the best locations was to apply six criteria (Being in a state of emergency due to water shortage; Need in investment in the water supply system; Surface waters as the main source of water supply; Population number between 4,000 and 25,000 people; High level of total solids dissolved in groundwaters; Great potential for solar and wind energy production), crossed them in GIS software and classified into 'Most Feasible' and 'Feasible'. The result obtained identified RN with the bigger number of 'Most Feasible'municipalities and PE with the bigger number of 'Feasible' municipalities for groundwater desalination.

Keywords: Semi-arid; Water Supply System; Renewable Energy.

\section{Viabilidade de dessalinização de água subterrânea no nordeste brasileiro}

\begin{abstract}
Secas sazonais ocorrem no nordeste do Brasil há séculos, devido à escassez de água causada pela seca severa de 2012-2018, os governos estaduais declararam estado de emergência para a maioria dos municípios. Como a maioria dos municípios depende de águas superficiais para o sistema urbano de abastecimento e a maioria dos reservatórios de água do Nordeste estando em uma situação crítica, a dessalinização das águas subterrâneas seria uma solução viável. Este trabalho tem como objetivo identificar municípios em situação de emergência nos estados do Ceará (CE), Rio Grande do Norte (RN), Paraíba (PB) e Pernambuco (PE) viáveis para a implementação de uma usina de dessalinização de destilação a qual utiliza fonte renovável de energia. Nesse contexto, o método utilizado para descobrir as melhores localizações foi aplicar seis critérios (Estar em estado de emergência devido à escassez de água; Necessidade de investimento no sistema de abastecimento de água; Águas superficiais como principal fonte de abastecimento; Número da população entre 4.000 e 25.000 pessoas; Alto nível de sólidos totais dissolvidos nas águas subterrâneas; Grande potencial para produção de energia solar e eólica), cruzou-os em um software SIG e classificou-os em 'Mais Viável' e 'Viável'. O resultado obtido identificou RN com o maior número de municípios 'Mais Viável' e PE com o maior número de municípios 'Viável' para dessalinização de águas subterrâneas.
\end{abstract}

Palavras-chave: Semiárido; Sistema de Abastecimento de Água; Energia renovável.

Topic: Engenharia Ambiental

Reviewed anonymously in the process of blind peer.
Received: 05/08/2020

Approved: 26/09/2020
Rafael Carneiro de Souza Barros (iD)

Universidade Federal da Paraíba, Brasil

http://lattes.cnpq.br/3245747863985366

http://orcid.org/0000-0003-3214-2292

rafaelhc3@gmail.com

Yasmim Cristina Leiros Meira (DD

Universidade Federal do Rio Grande do Norte

http://lattes.cnpq.br/6755944484620765

http://orcid.org/0000-0002-6990-3246

yasmimleiros@gmail.com
Referencing this:

BARROS, R. C. S.; MEIRA, Y. C. L.. Feasibility of groundwater desalination in the northeast of Brazil. Revista Ibero Americana de Ciências Ambientais, v.11, n.5, p.331-338, 2020. DOI: http://doi.org/10.6008/CBPC2179-6858.2020.005.0031 


\section{INTRODUCTION}

The Semi-arid region in Northeast of Brazil faces seasonal droughts by centuries and have faced one of the most severe on 2010 decade. The Brazilian Semi-arid has an area of $1542000 \mathrm{~km}^{2}$ and is the most populated semi-arid region in the world (MARENGO et al., 2016). It has as main characteristics the low rate of rainfall, high rate of evaporation and shallow soil.

The climate projections for the Northeast of Brazil are the decreasing of $10 \%$ to $20 \%$ of rainfall rates and an increasing of temperature of 0,5 to $1^{\circ} \mathrm{C}$ until 2040 (GUIMARAES et al., 2016). In a long term, the rainfall deficit allied with temperature increasing and more often droughts, would intensify the environment degradation in semi-arid region (MARENGO et al., 2016). In reason to these, preventive actions should be taken in order to help to cope issues those changes will cause.

At Brazilian semi-arid region, the shallow soils capping on crystalline rocks permit low water exchange between the river and the surrounding soil, allied with lack of rainfall, foster low volume of runoff water from rivers. That scenario also provides physical-chemical characteristics to the groundwater, making not suitable for human consumption (FERREIRA et al., 2017). These characteristics involve high rates of salt concentration in most of the semi-arid groundwater. The mainly cause of brackish and saline groundwaters is the evaporation (IGRAC et al., 2009).

The sources of water in the region are surface waters accumulated into reservoirs and groundwater. The groundwater has two main occurrences in rocks aquifer, at sedimentary rocks and at crystalline and karst rocks. At sedimentary rocks, the quantity and quality of water are larger and better, in comparison to the crystalline and karst rocks.

Most of the semi-arid region is under crystalline or karst rocks, which only provide groundwater by, fractured aquifers. This sort of aquifer is characterized by fractures, discontinuities, dissolution, making reservoirs discontinuous and irregular, with low or high potential according by its dimensions. In addition, fractured aquifers have average flow of $2.000 \mathrm{l} / \mathrm{h}$ (FEITOSA et al., 2011) and the quality of groundwater is mainly brackish and saline, with an average of $3.523,99 \mathrm{mg} / \mathrm{l}$ of Total Dissolved Solids (TDS) (FERREIRA et al., 2017).

The area of this study are the states of Ceará (CE), Paraíba (PB), Pernambuco (PE) and Rio Grande do Norte (RN), which are the ones most suffer from droughts. Together they are named Northern Semi-arid being one of the poorest regions in Brazil, their population lives in tough conditions with lacking basic infrastructures and the most of territory inserted in semi-arid region.

As most of the municipalities depending on surface waters for urban water supply, a large number of municipalities faced severe water use restrictions, the state governments have declared a state of emergency for most of the municipalities inserted in the semi-arid region due to scarcity of water. In this situation, different approaches for water supply are needed in order to provide water with substantial quality and quantity for population necessities. For instance, the federal government provides water supply for some municipalities by water trucks. 
The aim of this study is to identify municipalities, which might be feasible the use of groundwater by distillation desalination plant, which does not produce brine, as a source of water for municipalities or private purposes following selected criteria presented in the methods of analysis.

\section{METHODOLOGY}

The present study selected six criteria to analyse where would be feasible the use of groundwater of fractured aquifers with the average flow of $48 \mathrm{~m}^{3} /$ day by a desalination plant of capacity of $1,000 \mathrm{~m}^{3} /$ day and renewable energy as a power source, in municipalities of the states of Ceará (CE), Paraíba (PB), Pernambuco (PE) and Rio Grande do Norte (RN).

In order to analyse the data and achieve the desired outcome was used a GIS software against the selected criteria, discovering the 'most feasible' and 'feasible' municipalities. The difference between 'Most Feasible' and 'Feasible' municipalities are the TDS level in groundwater and the potential of renewable energy use. The 'Most Feasible' municipalities have presented most of the samples with TDS level above 5,000 mg/l, while 'Feasible' municipalities presented most of the samples with TDS level between 3,500 to 5,000 mg/l.

The criteria applied for municipalities were: I - Being in a state of emergency due to water shortage (data collected from the Integrated System of Disasters Information (S2ID)): this criterion was chosen because it informs municipalities most impacted by water scarcity; II - Need in investment in the water supply system (data collected from the Atlas of Urban Water Supply): chosen because informs which municipalities in normal water supply situation cannot provide water for the entire population in a correct manner; III Surface waters as the main source of water supply (data collected from the Atlas of Urban Water Supply): selected due to informing which cities do not use groundwater as the main source of water supply; IV Population number between 4,000 and 25,000 people (data collected from the Brazilian Institute of Geography and Statistics (IBGE)): this criterion was applied because it is the range of people the desalination plant can provide water in a day using local distribution manipulation; $V$ - High level of total solids dissolved in groundwaters (data collected from the Brazilian Geologic Service (CPRM) reports): elected in reason of desalination plants require brackish or salt waters and as higher is the level of Total Dissolved Solids (TDS) saltier is the water and more feasible is the machine use; VI - Great potential for solar and wind energy production (data collected from the Brazilian Atlas of Solar Energy and Wind Energy Atlas of the states PB, $\mathrm{PE}, \mathrm{RN}$ ): criterion was chosen because desalination plants demand a great amount of electricity and the use of renewable energy is more sustainable in long term than of grid electricity.

The criteria have had a qualitative, quantitative analysis and visual analysis for criteria V and VI, the visual analysis took into consideration the map of Feitosa (2011) and maps of the potential of solar and wind energy generation and locations of solar and wind farms.

\section{RESULTS}

Was analysed all the municipalities in the four states, which have declared state of emergency in the year of 2018, in total was 556 cities according to the S2ID. Table 1 shows the number of municipalities in 
each state.

Table 1: Municipalities in a state of emergency.

\begin{tabular}{lllll}
\hline State & $\begin{array}{l}\text { Total } \\
\text { municipalities }\end{array}$ & $\begin{array}{l}\text { number } \\
\text { emergency }\end{array}$ & $\begin{array}{l}\text { Municipalities in a state of } \\
\text { Municipalities in a } \\
\text { emergency (\%) }\end{array}$ \\
\hline Ceará (CE) & 184 & 89 & 48 \\
Paraíba (PB) & 223 & 195 & 85 \\
Pernambuco (PE) & 184 & 119 & 60 \\
Rio Grande do Norte & 167 & 153 & 90 \\
(RN) & & & & \\
\hline
\end{tabular}

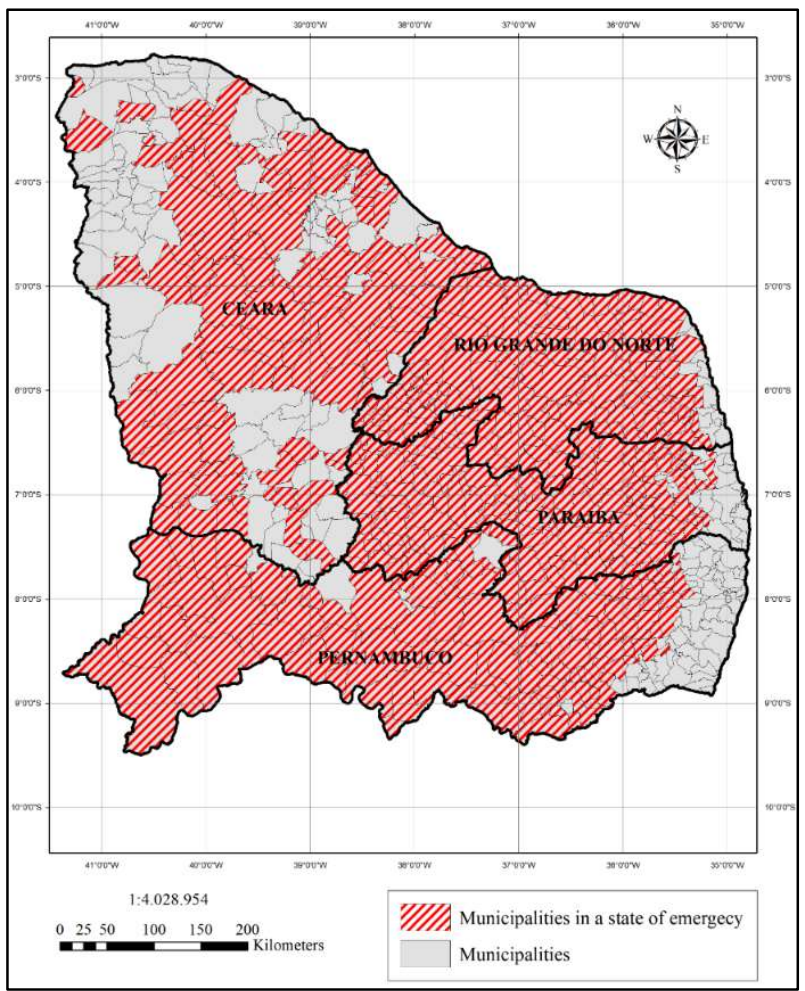

Figure1: Municipalities in a state of emergency

The figure 1 illustrates the municipalities in a state of emergency in each studied state. In regards to the number of municipalities needing investments in the water supply system is demonstrated in table 2 .

Table 2: Municipalities in a state of emergency needing investment in water supply system.

\begin{tabular}{llll}
\hline State & $\begin{array}{l}\text { Municipalities in a state } \\
\text { of emergency }\end{array}$ & $\begin{array}{l}\text { Municipalities needing investment } \\
\text { in water supply system }\end{array}$ & $\begin{array}{l}\text { Municipalities needing investment in } \\
\text { water supply system (\%) }\end{array}$ \\
\hline Ceará (CE) & 89 & 72 & 80 \\
Paraíba (PB) & 195 & 119 & 61 \\
Pernambuco (PE) & 119 & 84 & 71 \\
Rio Grande do & 153 & 87 & 60 \\
Norte (RN) & & & \\
\hline
\end{tabular}

Figure 2 illustrates the spatial distribution of municipalities needing investment in the water supply system. About the main source of water supply, it is shown in table 3. The Table 4 shows the level of TDS in some municipalities in Paraíba (PB), Pernambuco (PE) and Rio Grande do Norte (RN). Those measurements were done and report by the Brazilian Geologic Service (CPRM), which monitored wells in the municipalities. Table 5 displays the amount of power generated from wind farms and direct solar irradiation for each state. The results of crossing data from the selected criteria are seen in table 6 and figure 3 . 


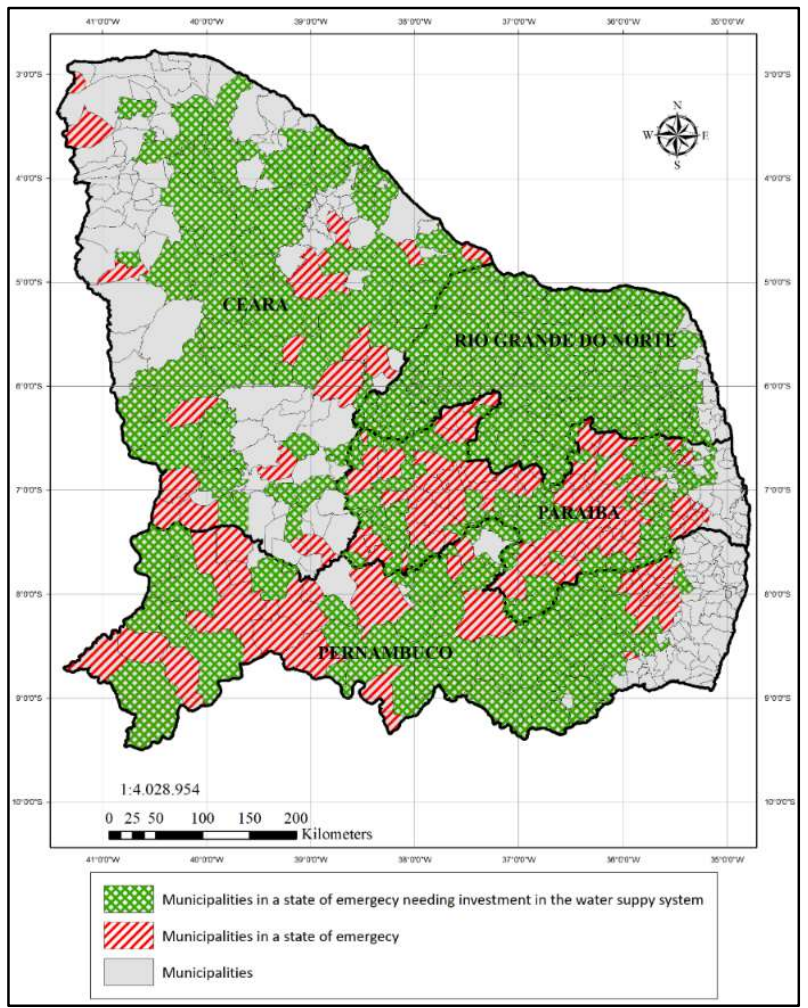

Figure 2: Municipalities in a state of emergency needing investment in water supply system.

Table 3: Source of water of the water supply system.

\begin{tabular}{llll}
\hline State & Surface waters (\%) & $\begin{array}{l}\text { Groundwater } \\
(\%)\end{array}$ & $\begin{array}{l}\text { Surface and Groundwaters } \\
\text { (\%) }\end{array}$ \\
\hline Ceará (CE) & 65 & 30 & 5 \\
Paraíba (PB) & 77 & 13 & 0 \\
Pernambuco (PE) & 82 & 11 & 7 \\
Rio Grande do Norte (RN) & 57 & 20 & 23 \\
\hline
\end{tabular}

Table 4: Wells analysed in municipalities.

\begin{tabular}{lllll}
\hline Municipality & State & Number of wells analysed & Lower level of TDS (mg/l) & $\begin{array}{l}\text { Higher level of TDS } \\
\text { (mg/l) }\end{array}$ \\
\hline Apodi & RN & 338 & 28.6 & 89,700 \\
Aracagi & PB & 25 & 129.35 & 51,740 \\
Araruna & PB & 43 & 213.83 & 32,500 \\
Areia Branca & RN & 43 & 208 & 23,530 \\
Buique & PE & 161 & 57.85 & 19,110 \\
Santana de Boa Vista & PE & 138 & 255.45 & $12,993.5$ \\
\hline
\end{tabular}

Table 5: renewable energy in the states.

\begin{tabular}{lll}
\hline State & Wind Power Generation (GWh/year) & Direct Solar Irradiation (KWh/m $\mathbf{m}^{\mathbf{2}}$.year) \\
\hline Ceará (CE) & $5,101.1$ & $1,800-2,200$ \\
Paraíba (PB) & 250.7 & $1,800-2,400$ \\
Pernambuco (PE) & $2,937.4$ & $1,800-2,200$ \\
Rio Grande do Norte (RN) & $13,243.2$ & $1,800-2,200$ \\
\hline
\end{tabular}

Table 6: Number of Most Feasible and Feasible municipalities.

\begin{tabular}{lll}
\hline State & Number of Most Feasible municipalities & Number of Feasible municipalities \\
\hline Ceará & 12 & 19 \\
Paraíba & 7 & 32 \\
Pernambuco & 7 & 36 \\
Rio Grande do Norte & 13 & 29 \\
\hline
\end{tabular}




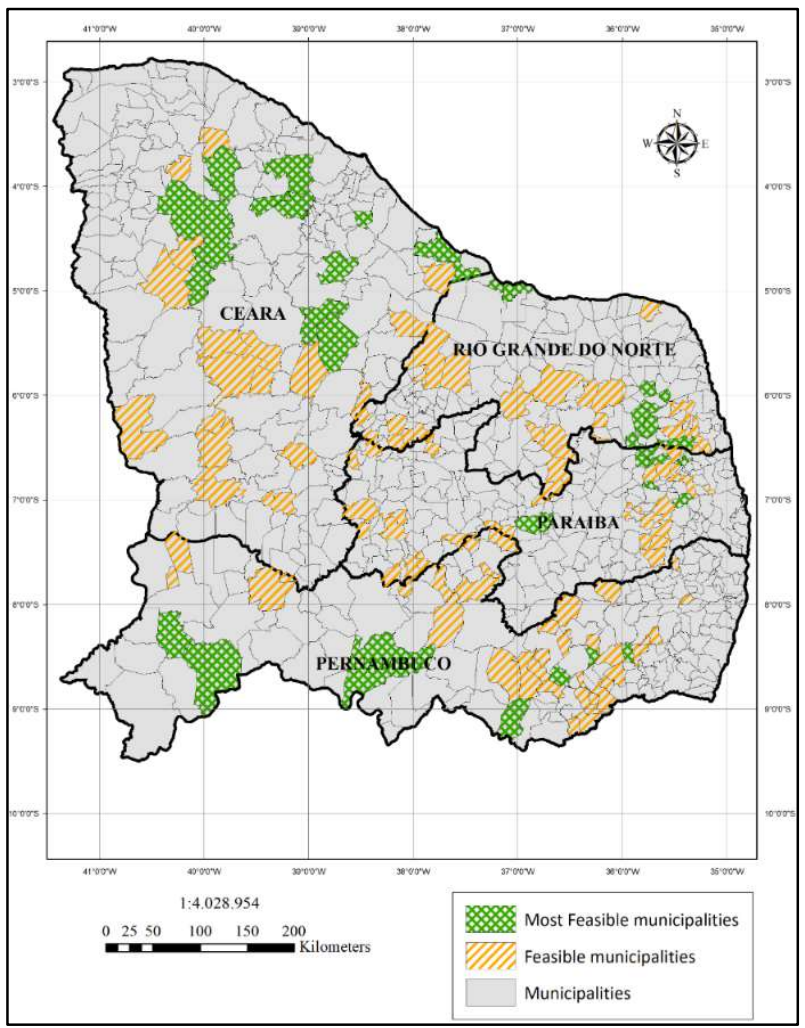

Figure 3: Municipalities Most Feasible and Feasible.

\section{DISCUSSION}

The two states most affected Rio Grande do Norte and Paraíba have fewer financial resources in comparison to Pernambuco and Ceará which are the two states less affected by water scarcity. With a restricted amount of financial support from the state government, municipalities had to declare a state of emergency to have access to federal funds in order to provide water for the population, mainly in rural areas in which most communities do not have running water in their homes.

From table 2 is possible to state that besides being the state with fewer municipalities in a state of emergency Ceará has the biggest number of cities needing investment in the water supply system. On the other hand, Paraíba which has the biggest number of cities in a state of emergency has the lowest number of municipalities in need of investment in the water supply system. While Pernambuco and Rio Grande do Norte has roughly the same number of municipalities in need. It is possible to say that the majority of municipalities require investment in this area mainly due to lack of proper infrastructure, lack of water source in close areas or outdated gear.

In terms of the source of water in urban water supply in all four states, surface waters dominate followed by groundwater. Pernambuco has $82 \%$ of surface water source and Ceará leads the use of groundwater with $30 \%$ of the municipalities. While Rio Grande do Norte has $23 \%$ of urban areas supplied by surface and groundwaters.

Ceará and Rio Grande do Norte has bigger areas of sedimentary soil, which tend to have groundwater with good quality and quantity. Because of this, the use of groundwater in sedimentary soil inclines to be higher, predominately in coastal areas. Pernambuco and Paraíba have low use of groundwater compared to Ceará and Rio Grande do Norte in consequence of crystalline soil that tends to provide groundwater with a 
high level of salts and low flow of water.

According to the table 4 , the variety of numbers of salinity goes from freshwater $(<1,000 \mathrm{mg} / \mathrm{l}$ of TDS) to saline waters (>10,000 $\mathrm{mg} / \mathrm{l}$ of TDS), in the same municipality. The reason for this lies in the characteristics of the type of soil. Those numbers just confirm the unpredictable quality of groundwater in the semi-arid region. It is possible to observe that the higher level of TDS is $89,700 \mathrm{mg} / \mathrm{l}$ and the lower $28.6 \mathrm{mg} / \mathrm{l}$. Regarding the state of Ceará, the analysis of data was qualitative, once the reports do not expose quantitative data only qualitatively, classifying the water of wells into fresh, brackish and saline. From the reports, it was possible to observe that the majority of the wells have the water classified as brackish water or saline water.

In relation to renewable energy generation, the Northeast has the best potential for wind and solar power. Referring to solar power, all states have similar conditions with Paraíba having slightly better potential. In addition, Northern semi-arid of Brazil has on average more than $2000 \mathrm{KWh} / \mathrm{m}^{2}$ of annual solar irradiation and low cloud cover, global horizontal irradiation of $5.49 \mathrm{KWh} / \mathrm{m}^{2}$.day and irradiation on tilted planes of $5.52 \mathrm{kWh} / \mathrm{m}^{2}$.day (INPE, 2017).

According to Silva et al. (2018), the use of photovoltaic panels to desalinate groundwater in the Northeast of Brazil is feasibly in municipalities with up to 20,000 (twenty thousand) inhabitants. This converges to the number of populations adopted in criterion III used in this study. Furthermore, Silva et al. (2019) state that small scale desalination plants powered by photovoltaic panels presented financial feasibility, producing water below water global index price. In the studied area 49 wind power farms generate 21,532.4 GWh/year (ABEE, 2017). From table 5 is possible to state that Rio Grande do Norte are the lead in wind power generation while Paraíba is the minor generator. These numbers are directly linked to the number of wind farms in each state.

Rio Grande do Norte and Ceará are the states with more Most Feasible municipalities, however are the two ones with less Feasible municipalities, while Paraíba and Pernambuco have roughly the same numbers. The number of Feasible municipalities is three times the number of Most Feasible, the reason for this fact lies in the case that majority of cities do not support the criteria of TDS level and potential for renewable energy generation at the optimum level.

As could be seen in the figure 3, the Most Feasible and Feasible municipalities are generally in a group or pair. It is hard to observe an isolated Most Feasible or Feasible municipality, which shows that the region is propitious for desalination plant implementation. This is helpful for those municipalities due to the high price of the investment in desalination plants.

Making a consortium between municipalities and incentive national production of desalination plants could be a great solution to lowering the costs and turn the investment in reality. In addition, the lack of studies on this theme difficult the investment in desalination solutions that would benefit populations to face water shortage.

\section{CONCLUSIONS}

In the study area, the groundwater has high levels of salts; there is a large quantity of solar irradiation; 
in some areas, propitious winds to generate energy; the necessity of investment in the water supply system and scarcity of freshwater. All these elements indicate that the utilization of a sustainable desalination plant is a good manner to bring water security for municipalities.

With the majority of municipalities exploring surface waters to supply urban areas, it might indicate that the groundwater reservoirs are stored and safe, ready to be used as an additional source of water for population. The high potential of renewable energy such as solar and wind power makes the Northeast the best place in Brazil to use these sorts of energy. Using wind turbines and solar panels to run desalination plants reduces the costs of operations and make it a sustainable process.

To conclude, the need for potable water in municipalities in the state of emergency combined with the potential development in living conditions and financial aspects through implantation of a sustainable desalination plant leads to the investment in groundwater desalination in Ceará, Paraíba, Pernambuco, and Rio Grande do Norte.

\section{REFERENCES}

ABEE. Associação Brasileira de Energia Éolica. Annual wind energy report. São Paulo, 2017.

FEITOSA, F. A. C.. Aspectos sobre água subterrânea em terrenos cristalinos da região semiárida brasileira. In: WORLD WATER CONGRESS, 14. Anais. Pernambuco, 2011.

FEITOSA, F. A. C.; FEITOSA, E. C.. Realidade e perspectivas do uso racional de águas subterrâneas na região semiárida do Brasil. In: RECURSOS HÍDRICOS EM REGIÕES ÁRIDAS E SEMIÁRIDAS. Anais. Campina Grande: Instituto Nacional do Semiárido, 2011. p.269-303.

FERREIRA, S. F.; VEIGA, H. P.; SANTOS, R. G. B.; SAIA, A.; RODRIGUES, S. C.; BEZERRA, A. F. M.; HERMES, L. C.; MOURA, A.; CUNHA, L. H.. Sustainable desalination process: fresh water program. In: THE INTERNACIONAL DESALINATION ASSOCIATION WORLD. Anais. São Paulo, 2017.

GUIMARAES, S. O.; COSTA, A. A.; VASCONCELOS JÚNIOR, F. C.; SIVA, E. M.; SALES, D. C.; ARAÚJO JÚNIOR, L. M.; SOUZA, S. G.. Projeções de Mudanças Climáticas sobre o Nordeste Brasileiro dos Modelos do CMIP5 e do CORDEX. Revista Brasileira de Meteorologia, v.31, n.3, p.337-365, 2016. DOI: https://doi.org/10.1590/0102-778631320150150
IGRAC. International Groundwater Resources Assessment Centre. Global overview of saline groundwater occurrence and genesis. Utrecht: IGRAC, 2009.

INPE. Instituto Nacional de Pesquisas Espaciais. Atlas brasileiro de energia solar. 2.ed. São José dos Campos, 2017.

MARENGO, J. A.; CUNHA, A. P.; ALVES. L. M.. A seca de 201215 no semiárido do Nordeste do Brasil no contexto histórico. Revista Climanálise, v.3, p.49-54, 2016.

SILVA, G. D. P.; SHARQAWY, M. H.. Technoeconomic analysis of low impact solar brackish water desalination system in the Brazilian Semiarid Region. Journal of Cleaner Production, v.248, 2019. DOI: https://doi.org/10.1016/i.jclepro.2019.119255

SILVA, W. F.; SANTOS, I. F. S.; BOTAN, M. C. C. O.; SILVA, A. P. M.; BARROS, R. M.. Reverse osmosis desalination plants in Brazil: a cost analysis using three different energy sources, Sustainable Cities and Society, v.43, p.134-143, 2018. DOI: https://doi.org/10.1016/j.scs.2018.08.030

A CBPC - Companhia Brasileira de Produção Científica (CNPJ: 11.221.422/0001-03) detém os direitos materiais desta publicação. Os direitos referem-se à publicação do trabalho em qualquer parte do mundo, incluindo os direitos às renovações, expansões e disseminações da contribuição, bem como outros direitos subsidiários. Todos os trabalhos publicados eletronicamente poderão posteriormente ser publicados em coletâneas impressas sob coordenação da Sustenere Publishing, da Companhia Brasileira de Produção Científica e seus parceiros autorizados. Os (as) autores (as) preservam os direitos autorais, mas não têm permissão para a publicação da contribuição em outro meio, impresso ou digital, em português ou em tradução. 